\title{
Moult strategies of Cory's Shearwaters Calonectris diomedea borealis: the influence of colony location, sex and individual breeding status
}

\author{
Hany Alonso · Rafael Matias · José Pedro Granadeiro • \\ Paulo Catry
}

Received: 7 April 2008/Revised: 1 July 2008/Accepted: 16 October 2008/Published online: 14 November 2008

(c) Dt. Ornithologen-Gesellschaft e.V. 2008

\begin{abstract}
The replacement of old feathers is essential for birds, but it is also an energy-demanding task. As moult usually does not coincide with other stressful events in its annual cycle, such as reproduction and migration, the bird can optimise its use of time and energy allocated to different activities. There are very few studies comparing the moult strategies of populations with similar breeding calendars but occurring in areas of different habitat quality. Cory's Shearwaters Calonectris diomedea have a partial moult-breeding overlap, an unusual phenomenon among pelagic seabirds. We have compared the moult schedules in Cory's Shearwater colonies located in distinct environments (pelagic vs. coastal) and show that moult-breeding overlap is less extensive on Selvagem Grande, situated in deep oceanic waters, than on Berlenga, situated on the continental shelf. Colony attendance of failed breeders, most of which were moulting, was lower at Selvagem Grande than at Berlenga, which suggests that the feeding areas of birds from the former site are more distant from the colony. Failed breeders started to moult earlier than individuals still raising a chick, and breeding status had a stronger influence on determining the onset of wing-feather
\end{abstract}

Communicated by P. H. Becker.

H. Alonso · R. Matias · P. Catry $(\bowtie)$

Unidade de Investigação em Eco-Etologia,

Instituto Superior de Psicologia Aplicada,

Rua Jardim do Tabaco 34,

1149-041 Lisbon, Portugal

e-mail: paulo.catry@gmail.com

\section{J. P. Granadeiro}

Centro de Biologia Ambiental,

Museu Nacional de História Natural,

Rua da Escola Politécnica, 58,

1269-102 Lisbon, Portugal moult than colony location. Despite published evidence that internal circannual rhythms and external cues, such as variation in daylength, are important factors regulating moult schedules, it is clear that birds retain a considerable flexibility that allows them to respond to external factors in order to strategically manage time and energy in a way that is thought to maximise their fitness.

Keywords Berlenga - Breeding success .

Food availability $\cdot$ Moult flexibility $\cdot$ Selvagem Islands

\section{Introduction}

Moult is a costly process to birds because feather growth requires a substantial input of nutrients and energy (Rayner and Swaddle 2000) and because flight efficiency is impaired during feather replacement (Swaddle and Witter 1997; Hedenström and Sunada 1999). It is therefore rare for moult to coincide with other energy-demanding annual events, such as reproduction and migration (Payne 1969; Rubolini et al. 2002; Bridge 2006; Munro et al. 2006; Newton 2008). Circannual rhythms are involved in the regulation of these important seasonal processes (Gwinner 2003). One of the most important external cues to a good synchronisation of these rhythms is the photoperiod, a factor that varies in a predictable and regular fashion in most latitudes (Newton 2008). Despite this, circannual programmes achieve their biological function by interacting with other environmental cues, and thus different populations and individuals differ in the details of their moult strategies (Gwinner 2003; Helm and Gwinner 2006).

There is an extensive body of literature describing differences in moult strategies among populations of birds (Hemborg et al. 2001; Helm and Gwinner 2006; Munro 
et al. 2006), but most of these differences are related to differences in breeding phenology (Arroyo et al. 2004) or in migration schedules (Yuri and Rohwer 1997; Munro et al. 2006; Newton 2008). In contrast, there are only a few studies examining whether the flexibility in moult strategies is influenced by differences in food availability or habitat quality (Borras et al. 2004). Borras et al. (2004) showed that geographically close populations of Citril Finches Serinus citrinella had different moult rates, apparently related with habitat quality. Their study suggests that different environments and the consequent selective pressures may favour the occurrence of moult strategies adapted to local conditions (Borras et al. 2004; Helm and Gwinner 2006).

Moult strategies vary not only with species and different populations of one species, but also among individuals, which again may be a response to variations in time and energy available for the moult activity (Furness 1988; Barbraud and Chastel 1998). In general, breeding status has an influence on the onset of moult and, probably, in its rate (e.g. Hunter 1984; Furness 1988; Weimerskirch 1991; Barbraud and Chastel 1998). In two species of Giant Petrels Macronectes halli and M. giganteus, for example, failed breeders start to moult their feathers earlier and moult more feathers simultaneously than successful breeders (Hunter 1984). In the Yellow-Nosed- Albatross Thalassarche chlororhynchos, a species where individuals only renew part of their plumage each year, non-breeders or failed breeders replace more feathers than successful breeders. Again, these observations suggest that the time, nutrients and/or energy available for feather replacement must be a constraint that leads to the development of different strategies among individuals (Furness 1988).

Sexual dimorphism in body size and differences in the reproductive investment can also lead to divergent moult strategies between the sexes. The sex with lesser investment in parental care during chick-rearing can more readily allocate energy to feather replacement, which may explain sex-based differences in the timing of moult in many species (Svensson and Nilsson 1997; Hemborg and Merilä 1998).

The Cory's Shearwater Calonectris diomedea is a medium-sized petrel that reproduces in the North Atlantic and Mediterranean regions. The subspecies $C$. $d$. borealis nests on several islands located in the temperate and subtropical North-east Atlantic Ocean (Thibault et al. 1997). The timing of breeding of the different populations of this subspecies is very similar among the colonies of the Salvages (150 km south of Madeira and approx. $250 \mathrm{~km}$ from the African coast), Azores (mid-Atlantic ridge) and Berlengas (off the Portuguese coast) (Granadeiro 1991; Monteiro and Furness 1996; Thibault et al. 1997), and birds from different populations show extensive overlap in their winter quarters, most of which are situated in the South Atlantic (González-Solís et al. 2007).

Cory's Shearwaters are generally present on their breeding grounds from the end of February, with laying only taking place in late May and early June and the breeding season extending to late October or early November, when most chicks fledge (Granadeiro 1991; Thibault et al. 1997). Azorean $C$. $d$. borealis apparently display a partial overlap between reproduction and wing moult (Monteiro and Furness 1996), a phenomenon that is uncommon among long-distance migratory petrels (Bridge 2006). Cory's Shearwaters start primary moult in late August, while still raising chicks, and continue to moult until late October, just before migrating. In late March, after arriving from the wintering grounds, some birds are still growing their last primary, while others have completed their moult (Monteiro and Furness 1996). There is also some overlap of breeding with the moult of the tail and body feathers. However, Monteiro and Furness (1996) studied individual birds that were of unknown breeding status, which may cast some doubt upon the conclusion that there was a true moult-breeding overlap in their sample of study birds.

We have analysed the wing and tail feather moult strategies of Cory's Shearwaters of the borealis group in two populations that occur in contrasting environments. Berlenga is a small island located near the Portuguese coast, on the continental shelf, and is home to a few hundred pairs of Cory's Shearwater (Granadeiro 1991, 1993). Selvagem Grande [part of the Selvagem (Savage) archipelago] is a volcanic island surrounded by deep oceanic waters and home to a population of Cory's Shearwaters currently estimated at 30,000 pairs (Granadeiro et al. 2006). Despite the fact that these two sites are separated by approximately $1170 \mathrm{~km}$, there are no differences in the timing or duration of breeding activities of the respective Cory's Shearwaters. Hence, these sites are well-suited for a study of the influence of environmental conditions on moult strategies. Shearwaters nesting on Berlenga are close to the productive waters over the continental shelf, while those at Selvagem Grande live in a presumably less productive environment, which forces them to make longer foraging trips, both during incubation and chick-rearing, in order to obtain food (Granadeiro et al. 1998; Catry et al. 2008). The nearest Cory's Shearwater colony to Berlenga is many hundreds kilometres away, which suggests that birds from that colony face little intraspecific competition.

We have tested the hypothesis that Cory's Shearwaters strategically adjust the timing of moult and the extent of moult-breeding overlap in response to variations in energetic requirements and environmental conditions. By sampling individuals of known sex and breeding status at two locations with contrasting environments, we were able 
to evaluate the relative importance of exogenous factors and individual traits in determining moult strategies and to examine how these birds adjust moult-breeding overlap in response to different ecological contexts.

\section{Methods}

This study was carried out on Berlenga Island $\left(39^{\circ} 24^{\prime} \mathrm{N}\right.$, $9^{\circ} 30^{\prime} \mathrm{W}$ ) and on Selvagem Grande (also known as Great Salvage Island) $\left(30^{\circ} 09^{\prime} \mathrm{N}, 15^{\circ} 52^{\prime} \mathrm{W}\right)$.

In 2006, during the incubation period (end May-June), we selected 57 active nests on Berlenga and 142 on Selvagem Grande. These nests were monitored daily until both mates could be captured, ringed and their sex determined using site-specific discriminant functions based on bill measurements (Granadeiro 1993). Individuals with a score $>0.1$ were classified as males and those with a score $\leq 0.1$ as females. Birds with intermediate values were only sexed if paired with an individual of known sex or if their distinctive vocalizations (Thibault et al. 1997) were heard during handling. Using these criteria and cross-checking with nesting partners, our sex classification accuracy was $>99 \%$ (unpublished data).

Between 18 July and 3 August, we made daily visits to a subsample of nests with the aim of determining hatching dates. Thereafter, visits were repeated in September and October to assess chick survival.

Night-time visits were also carried out in September, October and March, and all landed adult birds were captured and assessed for moult. Work started $1 \mathrm{~h}$ after sunset and continued for as long as new birds could be captured. On Berlenga, captures took place between 10 and 20 September and between 2 and 8 October in 2006 and again in 27 and 28 March 2007. On Selvagem Grande, moult scores were taken between 10 and 20 September 2006, between 28 and 30 March 2007 and between 10 and 20 September 2007. Overall, 400 individuals were analysed for moult, 95 on Berlenga and 305 on Selvagem Grande. In each handled individual, we inspected primary feathers, secondaries and rectrices. The moult stage of each feather was scored according to a six-point scale: $0=$ old feather; $1=$ feather missing or in pin; $2=$ new feather emerging from the sheath, grown to up to one third of its maximum length; $3=$ grown between one third and two thirds; $4=$ between two thirds to full grown and with remains of waxy sheath or blood in calamus; $5=$ fully developed feather without remains of waxy sheath or blood in calamus (Monteiro and Furness 1996). The total score of the primaries of an individual was calculated as the sum of all its primary scores. Primary moult is descendent and generally symmetric in the two wings (Monteiro and Furness 1996); hence, only one wing was analysed.
In the rectrices, it proved to be very difficult to distinguish some feathers with scores 0 and 5; we therefore only evaluated whether the bird was in active tail moult and counted the number of feathers growing/missing, without calculating moult scores.

In terms of breeding, birds were grouped into active breeders (individuals that were raising a chick) and failed breeders (individuals that had failed the reproductive attempt, generally during incubation). Only one moult measurement per individual was included in the analyses.

Moult scores had a non-normal distribution. We used non-parametric analyses to test for differences in moult scores among groups of birds in relation to different variables (month, sex, breeding status, nesting colony). In these analyses, we did not correct for Julian date, but we always made sure that there were no differences in the mean date of moult-scoring between the groups being compared.

To examine possible interactions between the various factors studied on moult scores, we complemented the simpler non-parametric tests with a multivariate analysis. We used a general linear model (GLM) to simultaneously test the effect of colony location, Julian date, sex and breeding status on primary moult scores. Despite the fact that the normality assumptions in the distribution of the moult scores were not verified, we thought it reasonable to use the GLM approach, given that sample sizes are large and there are no evident outliers in our dataset (see Bart et al. 1998). For tail moult, for which no scores were calculated, we used a logistic regression to simultaneously test different predictor variables on the probability of a bird being in active feather replacement.

In the results, means are presented together with the standard deviation (SD), and all significance tests are twotailed.

\section{Results}

In September 2006, on Selvagem Grande, $10 \%$ of the birds examined $(n=108)$ were moulting their primary feathers. The individual with the most advanced moult was simultaneously growing its three innermost primaries (on 17 September). On Berlenga, 42\% of the birds observed in September $(n=71)$ were moulting their primary feathers, and there were individuals moulting up to five primaries simultaneously. The most advanced state involved birds moulting their fifth primary $(n=3$, the first on 15 September). The proportion of active breeders engaged in primary moult was significantly higher on Berlenga than on Selvagem (Fisher's exact test, $P=0.001$; Table 1, Fig. 1). The sample size for failed breeders was too small for a meaningful inter-colony comparison. 
Table 1 Percentage of Cory's Shearwaters Calonectris diomedea engaged in primary moult and mean primary moult scores of active and failed breeders at the colonies of Selvagem Grande and Berlenga

\begin{tabular}{|c|c|c|c|c|c|}
\hline Study location/survey period & Parameter & Active breeders & Failed breeders & Statistical test & $P$ \\
\hline \multirow[t]{2}{*}{ Selvagem Grande/September } & Moulting birds & $8 \%$ & $75 \%$ & & $<0.001$ \\
\hline & Moult score & $0.2 \pm 0.6(104)$ & $1.3 \pm 1(4)$ & $U=71.5$ & $<0.001$ \\
\hline \multirow[t]{2}{*}{ Berlenga/September } & Moulting birds & $28 \%$ & $88 \%$ & & $<0.001$ \\
\hline & Moult score & $1.4 \pm 3.3(54)$ & $6.7 \pm 6.3(17)$ & $U=155$ & $<0.001$ \\
\hline \multirow[t]{2}{*}{ Berlenga/October } & Moulting birds & $77 \%$ & $100 \%$ & & 0.32 \\
\hline & Moult score & $5.7 \pm 5.1(30)$ & $20.3 \pm 6.2(6)$ & $U=8$ & $<0.001$ \\
\hline
\end{tabular}

Statistical comparisons were made using Fisher's exact test and Mann-Whitney test

Data are presented as the mean \pm standard deviation where appropriate, with the sample size given in parenthesis

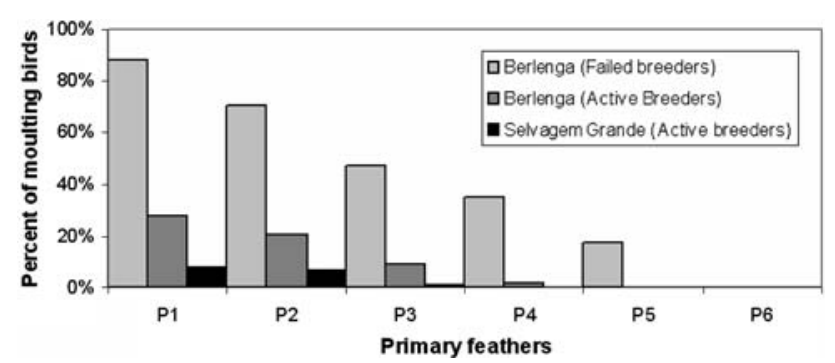

Fig. 1 Percentage of Cory's Shearwaters Calonectris diomedea moulting their primary feathers $(P 1-P 6)$ in September 2006 on Selvagem Grande (only active breeders, $n=104$ ) and on Berlenga (active and failed breeders: $n=54$ and $n=17$, respectively)

In October, on Berlenga, $81 \%$ of the birds captured $(n=36)$ had already started primary moult. The individuals with the most advanced moult state (three failed breeders) were moulting their sixth primary. There were 13 individuals with three primaries growing at one time.

At the end of March, all birds analysed on Berlenga $(n=39)$ had completed primary moult, while on Selvagem Grande we found only one bird (out of 153) with an incomplete primary moult, with a total score of 48 .

In September 2007, on Selvagem Grande, only 1.4\% $(n=71)$ of the active breeders were moulting their primaries, which is not significantly different from the value recorded in 2006 on the same dates (Fisher's exact test $P=0.085$ ).

Moult, sex and breeding status

In September, failed breeders presented a more advanced state of primary moult than active breeders in both colonies (Table 1, Fig. 1). There were no differences in the proportion of birds of each sex, at each site, engaged in active primary moult (Table 2). When we simultaneously tested the effects of date, site and breeding status on the primary moult score using a GLM, we were able to confirm most of the results described above (Table 3). However, sex appeared to have a significant effect on primary moult, with males presenting a more advanced moult (Tables 2, 3).

Secondary and tail moult

In September, none of the birds analysed at Selvagem Grande $(n=179)$ or at Berlenga $(n=71)$ were moulting their secondary feathers. The same was true in October at Berlenga $(n=36)$, although during this month we did capture an individual moulting six primaries and the first secondary. Because its breeding status was unknown, however, it could have been a non-breeding bird. In March, all birds had fresh secondaries, indicating they had been moulted over the winter.

In September, a few individuals in each colony were in active tail moult, with failed breeders being more likely to be growing new feathers (Table 4). On Berlenga, there was a positive correlation between the number of primaries and rectrices in active moult in failed breeders $(R=0.80$, $n=17, P<0.001)$, but not in active breeders $(R=0.08$, $n=54, P=0.55$ ).

In March 2007, 6.5\% of the birds ( $n=153$ ) on Selvagem and $7.7 \%(n=39)$ of those on Berlenga were in active tail feather moult.

When modelling all the variables together by a logistic regression, breeding status had an influence on the probability of an individual being engaged in active tail moult in September, while date, sex and colony site showed no significant effects (Table 5).

\section{Recapture frequencies in September}

The percentage of birds ringed during incubation that still had a chick in September and was recaptured during the moult survey in this month was $87 \%(n=64)$ on Berlenga and $41 \%(n=137)$ on Selvagem Grande. The corresponding values for failed breeders were $45 \%(n=50)$ on Berlenga and 5\% $(n=36)$ on Selvagem Grande. The results of the log-linear analysis show that active breeders 
Table 2 Percentage of Cory's Shearwaters with the primary moult initiated and mean primary moult scores of males and females in September 2006

\begin{tabular}{llllc}
\hline Breeding status (study site) & Parameter & Males & Females & Statistical test \\
\hline Active breeders (Selvagem Grande) & Moulting birds & $5 \%$ & $10 \%$ & 0.42 \\
& Moult score & $0.1 \pm 0.5(58)$ & $0.2 \pm 0.6(31)$ & $U=858.5$ \\
Active breeders (Berlenga) & Moulting birds & $29 \%$ & $26 \%$ & 0.42 \\
& Moult score & $1.9 \pm 4.2(31)$ & $0.6 \pm 1(23)$ & $U=332.5$ \\
Failed breeders (Berlenga) & Moulting birds & $89 \%$ & $88 \%$ & 0.6 \\
& Moult score & $9.4 \pm 7(9)$ & $3.6 \pm 3.9(8)$ & $U=20$ \\
\hline
\end{tabular}

Statistical comparisons were made using Fisher's exact test and the Mann-Whitney test

Data are presented as the mean \pm standard deviation where appropriate, with the sample size given in parenthesis

Table 3 Results of the GLM analysis on the effects of date, colony location, sex and breeding status on primary moult scores of Cory's Shearwaters in September

\begin{tabular}{lrrl}
\hline Effect & $d f$ & \multicolumn{1}{l}{$F$} & $P$ \\
\hline Date & 1 & 8.12 & 0.005 \\
Colony location & 1 & 11.07 & 0.001 \\
Sex & 1 & 5.56 & 0.020 \\
Breeding status & 1 & 11.05 & 0.001 \\
Col. location $\times$ breed. status & 1 & 4.69 & 0.032 \\
Error & 156 & & \\
\hline
\end{tabular}

Table 4 Percentage of active and failed breeders engaged in active tail moult at the colonies of Selvagem Grande and Berlenga

\begin{tabular}{lllll}
\hline $\begin{array}{l}\text { Breeding status } \\
\text { (study site) }\end{array}$ & Parameter & $\begin{array}{l}\text { Active } \\
\text { breeders }\end{array}$ & $\begin{array}{l}\text { Failed } \\
\text { breeders }\end{array}$ & $P$ \\
\hline $\begin{array}{c}\text { Selvagem Grande } \\
\quad \text { September) }\end{array}$ & Moulting birds & $9 \%(104)$ & $0 \%(4)$ & 1 \\
$\begin{array}{c}\text { Berlenga } \\
\quad \text { September) }\end{array}$ & Moulting birds & $15 \%(54)$ & $41 \%(17)$ & 0.04 \\
$\begin{array}{l}\text { Berlenga (October) } \\
\text { (S) }\end{array}$ & Moulting birds & $23 \%(30)$ & $67 \%(6)$ & 0.32 \\
\hline
\end{tabular}

Statistical comparisons were made using Fisher's exact test

Sample size is given in parenthesis

Table 5 Results of the logistic regression analysis of the influence of date, sex, breeding status and colony location on the probability of an individual being engaged in active tail moult $(n=162$ individual birds)

\begin{tabular}{lrcll}
\hline Variables & \multicolumn{1}{c}{$\beta$} & Standard error & $d f$ & $P$ \\
\hline Intercept & 32.67 & 20.62 & 1 & 0.11 \\
Date & -0.13 & 0.08 & 1 & 0.12 \\
Breeding status & 1.42 & 0.47 & 1 & 0.02 \\
Sex & 0.61 & 0.58 & 1 & 0.20 \\
Colony location & 0.62 & 0.51 & 1 & 0.23 \\
\hline
\end{tabular}

were more likely to be recaptured in September than failed breeders $(P<0.001)$ and that there was a significant interaction between site, breeding status and the proportion of birds recaptured in September $(P<0.001)$, suggesting that, irrespective of capture effort, failed breeders were more likely to be found at the colony on Berlenga than at the one on Selvagem Grande.

\section{Breeding success}

In 2006, the proportion of hatched chicks that survived until the end of September (date after which the mortality until fledging is negligible) was $0.88(n=34)$ on Berlenga and $0.88(n=64)$ on Selvagem Grande. The mean date of hatching on Berlenga $(n=34)$ and Selvagem Grande $(n=63)$ was similar ( $t$ test $-0.726, d f=95, P=0.47)$, with the mean value at both sites being 25 July. In 2007, the mean date of hatching on Selvagem Grande was 24 July $(N=57)$.

\section{Discussion}

The results of this study show that there are considerable differences in the timing of moult and in the overlap of moult with reproduction in Cory's Shearwaters breeding under contrasting environments. Together with the marked contrast in the timing of moult of active and failed breeders, these facts highlight the importance of exogenous factors in determining the moult strategies of this species.

Breeding status strongly influenced moult schedule

Among the variables studied, breeding status was, by far, the most influential in determining the onset of wing and tail-feather moult. Failed breeders started the moult earlier than individuals still engaged in chick-rearing. This pattern fits well with that reported for other seabirds, where nonbreeders or failed breeders take advantage of their off-duty status to engage in moult while resources are presumably still plentiful during normal breeding seasons (Hunter 1984; Furness 1988; Barbraud and Chastel 1998). In our study, most failed individuals had lost their offspring 
during incubation or early chick-rearing (late May-early August), as is typical for the species (e.g. Ramos et al. 2003), and probably had been off-duty for several weeks before the observations took place in September. At that point, these birds should have more time and energy available to allocate to other activities. Although failed breeders began moult sooner, we could not determine whether they demonstrated a more rapid moult progression because too few birds observed to be moulting in September were captured again in October. What is clear from our data is that the large majority $(77 \%)$ of the individuals still engaged in reproduction in early October had already started wing moult, which confirms that Cory's Shearwaters do present a true moult-breeding overlap. This overlap suggests that, at least in some areas, food resources are plentiful in late summer and early autumn, during the final stages of the breeding cycle of this species. Available data (Monteiro and Furness 1996; this study) does not allow us to determine whether Cory's Shearwaters suspend their moult during their migratory journeys-in late October and November-or if they can start migration while still in active moult.

The differences in the moult strategies of active breeders and off-duty birds provide supporting evidence to the idea that major events in the annual cycles of birds are separated due to, among other factors, a limitation in available resources (energy or nutrients) at any particular moment. Individual birds exhibit an interesting flexibility in the strategic management of those resources in face of competing needs for reproduction, maintenance and survival.

\section{Moult progress differed between populations}

Several studies have found that different populations of a species can display distinct moult strategies and that these are generally related to differences in the timing of reproduction and migration in different parts of the breeding range (e.g. Arroyo et al. 2004; Newton 2008). Fewer studies have documented intra-specific differences that can be attributed to variations in habitat quality (e.g. Borras et al. 2004). If moult is constrained by the availability of feeding resources, it can be predicted that birds nesting in more favourable locations are better able to overlap breeding and moult. This prediction seems to be supported by our data on Cory's Shearwaters. Despite the lack of differences in breeding phenology, moulting schedules were undoubtedly distinct, with more moultbreeding overlap on Berlenga.

Individuals nesting on Selvagem Grande generally make much longer foraging trips than birds nesting on Berlenga (Granadeiro et al. 1998; Catry et al. 2008). This is presumably a result of the lower productivity of the ocean in pelagic waters and, possibly, because of increased intra- specific competition in pelagic waters in comparison to waters over the continental shelf, where birds face less competition and the smaller colony may be limited by nesting site rather than food availability. In fact, birds on Selvagem not only make longer foraging trips during incubation (Catry et al. 2008), but also they can engage in a dual strategy of mixed short and long foraging trips during chick rearing (Granadeiro et al. 1998). These activities are indicative of a shortage of resources in the vicinity of the colony (Chaurand and Weimerskirch 1994; Weimerskirch et al. 1997). Nest attendance on Selvagem Grande is also lower than on Berlenga (Granadeiro et al. 1998), and the feeding frequency of the chicks is more variable at the former site (Granadeiro et al. 1998; Ramos et al. 2003). Given that the breeding phenology of Cory's Shearwaters on Berlenga and Selvagem Grande is virtually identical (Thibault et al. 1997; this study), one might expect similar moulting schedules at both sites (Monteiro and Furness 1996). The fact that primary and tail moult starts later at Selvagem Grande is in line with the prediction of less moult-breeding overlap in less favourable environments.

One further line of evidence suggesting that the sea around Selvagem Grande is less productive is provided by data on the recapture rates of failed breeders at the colonies in September. The probability of recapturing failed breeders (as compared to active breeders) was clearly lower on Selvagem Grande than on Berlenga, which indicates that the presence of failed breeders was lower on Selvagem, irrespective of differences in recapture effort. This result suggests that failed breeders, once unbound from their nesting duties, moved elsewhere to moult, presumably searching for better foraging grounds. The few failed breeders recaptured at Selvagem were, as on Berlenga, mostly in active wing moult.

It is also interesting to note that, despite other differences between colonies, fledging success was similar in colonies on Berlenga and Selvagem, suggesting that the first priority of parents was to allocate resources to raising chicks - at the expense of moult in the least productive area. The nonbreeding period in this species is presumably long enough to enable a complete renewal of the feathers later in the annual cycle, without compromising residual reproductive value, which is known to generally take precedence over the needs of the chicks in long-lived pelagic seabirds (Mauck and Grubb 1995; Navarro and González-Solís 2007).

In relation to the situation reported for Cory's Shearwaters in the Azores, any comparison with published results must be done with caution, given that the breeding status of the birds analysed by Monteiro and Furness (1996) is unknown and, according to our results, breeding status is a major determinant of moult progression. Still, both active and failed breeders on Selvagem had much lower moult scores than the birds analysed by Monteiro 
and Furness (1996), which implies that the onset of moult of Cory's Shearwaters in the Azores occurs earlier than in Selvagem. This difference suggests that, in other places, Cory's Shearwaters can have a greater overlap between moult and reproduction, even when breeding in oceanic islands distant from major continental shelves.

\section{Moult does not differ between sexes}

Parental investment (Svensson and Nilsson 1997) and sexual dimorphism (Weimerskirch 1991) can influence the moult strategies of birds, leading to differences in the timing of moult between sexes (Svensson and Nilsson 1997) or even in the extent of annual moult (Weimerskirch 1991). Male Cory's Shearwaters are substantially larger than females (Granadeiro 1993; Thibault et al. 1997), but there is little evidence for sexual differences in the foraging strategies of Cory's Shearwaters during chick-rearing (Granadeiro et al. 1998; Navarro et al. 2007). This is in contrast with information reported for a number of other petrels (e.g. Weimerskirch et al. 1997; Gray and Hamer 2001). It is known that, during the pre-breeding stage, males of Cory's Shearwaters play a major role in nestguarding and have higher nest attendance levels (Jouanin et al. 2001) and that, on the other hand, females must support the costs of egg production. However, these costly activities are well separated from the time when primary moult takes place. Although we found no differences between sexes in the proportion of moulting birds, the GLM analysis reported a significant effect of sex on primary moult scores, which might suggest that males, once started, moult more primaries simultaneously. More detailed data will be needed to assess the magnitude and biological significance of this difference. In any case, it seems that even if a difference exists, it is of a relatively small magnitude (see also Monteiro and Furness 1996).

\section{Tail moult}

Although generally fitting with the results from the study of primary moult, the patterns of tail feather replacement were not totally in line with those of wing moult. In particular, when we compared birds at distinct nesting grounds, there were no significant differences. However, one must keep in mind that the pattern and schedule of the moult of rectrices is distinct from that of the moult of primaries (Monteiro and Furness 1996). The onset of the moult of tail feathers takes place in the wintering areas. Moult is well advanced by March, it then suffers an interruption during June and July and, in September, there are only a few birds moulting their rectrices (Monteiro and Furness 1996). In our study on Berlenga, we found that the proportion of birds moulting their tail feathers (irrespective of being active breeders or failed breeders) rose from September to October, in contrast with the observations made in the Azores (Monteiro and Furness 1996). Again, we must keep in mind that the data from the Azores involve birds of unknown breeding status, which may influence any conclusions. Still, the proportions of birds actively moulting their rectrices in March on Berlenga (6.5\%) and on Selvagem (7.7\%) were much lower than that one found in the Azores $(37.5 \%)$. More research is needed to assess the relevance and causes of such differences.

\section{Conclusions}

The results of our study confirm that moult strategies within a species are flexible and that individuals can manage the competing needs of resources for moult and reproduction while still responding to the variability in environmental conditions in different areas, irrespective of the timing of breeding. More studies are needed to assess if differences in habitat quality commonly result in differences in moulting schedules. Furthermore, the analysis of factors such as body condition, age (Barbraud and Chastel 1998; Newton and Rothery 2005) and experience (Weimerskirch 1991) of the study birds could help to achieve a better understanding of the influence of external and internal factors in the flexibility of moult strategies in Cory's Shearwaters and other birds.

\section{Zusammenfassung}

Mauserstrategien des Gelbschnabel-Sturmtauchers Calonectris diomedea borealis: der Einfluss von Koloniestandort, Geschlecht und individuellem Brutstatus

Das Ersetzen alter Federn ist für Vögel essentiell, jedoch auch mit Energieaufwand verbunden. Vermutlich fällt Mauser normalerweise nicht mit anderen anstrengenden Ereignissen im Jahreszyklus, wie Fortpflanzung und Zug, zusammen, so dass der Vogel die Nutzung von Zeit und Energie, die unterschiedlichen Aktivitäten zugeteilt werden, optimieren kann. Es gibt nur sehr wenige Studien, welche die Mauserstrategien von Populationen mit ähnlichen Brutkalendern, die in Gebieten unterschiedlicher Habitatqualität vorkommen, vergleichen. Bei Gelbschnabel-Sturmtauchern Calonectris diomedea überlappen Mauser und Brut teilweise, was für pelagische Seevögel ungewöhnlich ist. Hier vergleichen wir den Mauserablauf von Gelbschnabel-Sturmtaucher-Kolonien, die in unterschiedlichen Umwelten (pelagisch vs. Küste) lokalisiert sind, und zeigen, dass die Überlappung von Mauser und Brut auf Selvagem Grande (in tiefem Freiwasser) weniger 
ausgeprägt ist als auf Berlenga (am Kontinentalschelf). Auf Selvagem Grande waren weniger erfolglose Brüter, von denen die meisten mauserten, in der Kolonie anwesend als auf Berlenga, was darauf schließen lässt, dass die Nahrungsgebiete von Vögeln des ersten Standorts weiter von der Kolonie entfernt sind. Erfolglose Brüter begannen früher mit der Mauser als Individuen, die noch ein Küken aufzogen, und der Brutstatus hatte einen stärkeren Einfluss auf den Beginn der Mauser der Flügelfedern als der Koloniestandort. Trotz veröffentlichter Belege dafür, dass interne zirkannuale Rhythmen und externe Signale, z.B. Schwankungen der Tageslänge, wichtige den Mauserablauf regulierende Faktoren sind, ist es offensichtlich, dass Vögel eine beträchtliche Flexibilität bewahren, die es ihnen erlaubt, auf externe Faktoren $\mathrm{zu}$ reagieren, um Zeit und Energie derart zu verwalten, dass es vermutlich ihre Fitness maximiert.

Acknowledgments Paulo Oliveira, Dília Menezes and António Teixeira granted permission to carry out the research and, together with the wardens at the two Nature Reserves where this study took place, provided important logistical support. Luís Vicente helped with fieldwork. The manuscript benefited from the comments of two anonymous referees. This study is an output of a project on the ecology of Cory's Shearwaters (PDCT/MAR/58778/2004) supported by Fundação para a Ciência e a Tecnologia (FCT - Portugal). P. Catry was the recipient of postdoctoral fellowships from FCT (BPD/11631/ 02 and SFRH/BPD/30031/2006), and further support was received through Programa Plurianual (UI\&D 331/94).

\section{References}

Arroyo B, Minguez E, Palomares L, Pinilla J (2004) The timing and pattern of moult of flight feathers of European storm-petrel Hydrobates pelagicus in Atlantic and Mediterranean breeding areas. Ardeola 51:365-373

Barbraud C, Chastel O (1998) Southern fulmars moult their primary feathers while incubating. Condor 100:563-566. doi:10.2307/ 1369726

Bart J, Fligner MA, Notz WI (1998) Sampling and statistical methods for behavioural ecologists. Cambridge University Press, Cambridge

Borras A, Cabrera T, Cabrera J, Senar JC (2004) Interlocality variation in the speed of moult in the citril finch Serinus citrinella. Ibis 146:14-17. doi:10.1111/j.1474-919X.2004.00199.x

Bridge ES (2006) Influences of morphology and behavior on wingmoult strategies in seabirds. Mar Ornithol 34:7-19

Catry P, Matias R, Vicente L, Granadeiro JP (2008) Brood-guarding behaviour in Cory's shearwaters Calonectris diomedea. J Ornithol (in press). doi:10.1007/s10336-008-0322-x

Chaurand T, Weimerskirch H (1994) The regular alternation of short and long foraging trips in the blue petrel Halobaena caerulea: a previously undescribed strategy of food provisioning in a pelagic seabird. J Anim Ecol 63:275-282. doi:10.2307/5546

Furness RW (1988) Influences of status and recent breeding experience on the moult strategy of the yellow-nosed albatross Diomedea chlororhynchos. J Zool (Lond) 215:719-727

González-Solís J, Croxall JP, Oro D, Ruiz X (2007) Trans-equatorial migration and mixing in the wintering areas of a pelagic seabird.
Front Ecol Environ 5:297-301. doi:10.1890/1540-9295(2007) 5[297:TMAMIT]2.0.CO;2

Granadeiro JP (1991) The breeding biology of Cory's shearwater on Berlenga Island, Portugal. Seabird 13:30-39

Granadeiro JP (1993) Variation in measurements of Cory's shearwater between populations and sexing by discriminant analysis. Ring Migr 14:103-112

Granadeiro JP, Nunes M, Silva MC, Furness RW (1998) Flexible foraging strategy of Cory's shearwater Calonectris diomedea during the chick rearing period. Anim Behav 56:1169-1176. doi: 10.1006/anbe.1998.0827

Granadeiro JP, Dias MP, Rebelo R, Santos CD, Catry P (2006) Numbers and population trends of Cory's shearwater Calonectris diomedea at Selvagem Grande, Northeast Atlantic. Waterbirds 29:56-60. doi:10.1675/1524-4695(2006)29[56:NAPTOC]2.0.CO;2

Gray C, Hamer K (2001) Food provisioning behaviour of male and female Manx shearwaters Puffinus puffinus. Anim Behav 62:117-121. doi:10.1006/anbe.2001.1717

Gwinner E (2003) Circannual rhythms in birds. Curr Opin Neurobiol 13:770-778. doi:10.1016/j.conb.2003.10.010

Hedenström A, Sunada S (1999) On the aerodynamics of moult gaps in birds. J Exp Biol 202:67-76

Helm B, Gwinner E (2006) Timing of moult as a buffer in the avian annual cycle. Acta Zool Sin 52:703-706

Hemborg C, Merilä J (1998) A sexual conflict in collared flycatchers, Ficedula albicollis: early male moult reduces female fitness. Proc R Soc Lond B Biol Sci 265:2003-2007. doi:10.1098/rspb. 1998.0532

Hemborg C, Sanz JJ, Lundberg A (2001) Effects of latitude on the trade-off between reproduction and moult: a long-term study with pied flycatcher. Oecologia 129:206-212. doi:10.1007/ s004420100710

Hunter S (1984) Moult of the giant petrels Macronectes halli and M. giganteus at South Georgia. Ibis 126:119-132. doi:10.1111/ j.1474-919X.1984.tb07993.x

Jouanin C, Roux F, Mougin J-L, Stahl J-C (2001) Prelaying exodus of Cory's shearwaters (Calonectris diomedea borealis) on Selvagem Grande. J Ornithol 142:212-217. doi:10.1007/BF01651789

Mauck RA, Grubb TC (1995) Petrel parents shunt all experimentally increased reproductive costs to their offspring. Anim Behav 49:999-1008. doi:10.1006/anbe.1995.0129

Monteiro LR, Furness RW (1996) Moult of Cory's shearwater during the breeding season. Condor 98:216-221. doi:10.2307/1369139

Munro U, Funnell JR, Thomson AS (2006) Moult in captive partially migratory and sedentary Australian silvereyes (Zosterops lateralis) (Zosteropidae). J Ornithol 147:287-297. doi:10.1007/ s10336-006-0056-6

Navarro J, González-Solís J (2007) Experimental increase of flying costs in a pelagic seabird: effects of foraging strategies, nutritional state and chick condition. Oecologia 151:150-160. doi:10.1007/s00442-006-0559-0

Navarro J, González-Solís J, Viscor G (2007) Nutritional and feeding ecology in Cory's shearwater Calonectris diomedea during breeding. Mar Ecol Prog Ser 351:261-271. doi:10.3354/meps07115

Newton I (2008) The migration ecology of birds. Academic Press, London

Newton I, Rothery P (2005) The timing, duration and pattern of moult and its relationship to breeding in a population of the European greenfinch Carduelis chloris. Ibis 147:667-679. doi:10.1111/ j.1474-919X.2005.00439.x

Payne RB (1969) Overlap of breeding and moulting schedules in a collection of African birds. Condor 71:140-145. doi:10.2307/ 1366075

Ramos JA, Moniz Z, Sola E, Monteiro LR (2003) Reproductive measures and chick provisioning of Cory's Shearwater Calonectris diomedea borealis in the Azores. Bird Study 50:47-54 
Rayner JMV, Swaddle JP (2000) Aerodynamics in behaviour of moult and take-off in birds. In: Domenici P, Blake RW (eds) Biomechanics in animal behaviour. BIOS Sci Publ, Oxford, pp 125-157

Rubolini D, Massi A, Spina F (2002) Replacement of body feathers is associated with low pre-migratory energy stores in a longdistance migratory bird, the barn swallow (Hirundo rustica). J Zool (Lond) 258:441-447. doi:10.1017/S0952836902001590

Svensson E, Nilsson JA (1997) The trade-off between moult and parental care: a sexual conflict in the blue tit? Behav Ecol 8:9298. doi:10.1093/beheco/8.1.92

Swaddle JP, Witter MS (1997) The effects of moult on the flight performance, body mass, and behaviour of European starlings
(Sturnus vulgaris): an experimental approach. Can J Zool 75:1135-1146. doi:10.1139/z97-136

Thibault J-C, Bretagnolle V, Rabouam C (1997) Calonectris diomedea Cory's Shearwater. BWP Update 1:75-98

Weimerskirch H (1991) Sex-specific differences in moult strategy in relation to breeding in the wandering albatross. Condor 93:731737. doi: $10.2307 / 1368205$

Weimerskirch H, Cherel Y, Cuenot-Chaillet F, Ridoux V (1997) Alternative foraging strategies and resource allocation by male and female albatrosses. Ecology 78:2051-2063

Yuri T, Rohwer S (1997) Moult and migration in the northern roughwinged swallow. Auk 114:249-262 